\title{
THE UTILIZATION OF DOLOMITE AS CATALYST IN BIODIESEL PRODUCTION
}

\author{
Rita Olivia ${ }^{1}$, Novesar Jamarun ${ }^{2 *}$, Syukri Arif ${ }^{2}$ and Yenny Aydiyon Sirin ${ }^{3}$ \\ ${ }^{1}$ Vocational High School of Industry Technology, Padang Indonesia. \\ ${ }^{2}$ Departement of Chemistry, Andalas University, Padang, Indonesia. \\ ${ }^{3}$ Vocational High School of Chemistry Analyst, Padang, Indonesia. \\ *E-mail: novesar62@yahoo.com
}

\begin{abstract}
Biodiesel as a renewable fuel has much of public concern to reduce the human's dependence on fossil fuels. A catalyst is necessary for increasing the rate of biodiesel production. The progress of biodiesel synthesis is focused on the efficiency of production and reduction of its negative impact to the environment. In this study, dolomite was used as a heterogeneous catalyst which was environmentally friendly in biodiesel manufacturing. The mixed $\mathrm{CaO} . \mathrm{MgO}$ oxide was resulted through the calcinations stage of dolomite mineral on optimum temperature $\left(900^{\circ} \mathrm{C}\right)$. Before being applied as catalyst, mixed oxide was characterized by XRF, XRD, SEM and BET. The CaO.MgO oxide was applied as a catalyst in trans-esterification reaction of palm oil and methanol to form biodiesel. The reaction yielded $78.09 \%$ biodiesel with $15 \%$ catalyst ratio to oil for 60 minutes reaction under temperature of $60^{\circ} \mathrm{C}$. Dolomite can be used as a catalyst in the production of biodiesel from palm oil and methanol.
\end{abstract}

Keywords: characterization, dolomite, catalyst, biodiesel, palm oil

(C) RASĀYAN. All rights reserved

\section{INTRODUCTION}

Nowadays, many researcher's concerns are studying a renewable energy sources namely vegetable oils or animal fats. This material is transformed into Fatty Acid Methyl Ester known as FAME by using $\mathrm{NaOH}$ and $\mathrm{KOH}$ as homogenous catalyst. In general, some researchers have studied a method of making fatty acid methyl ester from palm oil through trans-esterification process by using $\mathrm{NaOH}$ and $\mathrm{KOH}$ as catalyst. $\mathrm{NaOH}$ and $\mathrm{KOH}$ catalysts have drawbacks such as high corrosive properties that can give negative impacts on machine tools. The catalyst may not be reused in the methyl ester and then it is released as waste of $\mathrm{NaOH}$ solution that's harmful for environment ${ }^{1}$. Many efforts have been made to reduce the negative impact of homogeneous catalyst and one of them is by using heterogeneous catalyst.

Biodiesel is a renewable fuel that can be obtained from the esterification reaction between vegetable oils or animal fats and methanol using a homogeneous catalyst or a heterogeneous catalyst ${ }^{2-7}$. Research on biodiesel is focused on production efficiency and efforts to minimize the environmental impact. The use of heterogeneous catalyst can minimize environmental impact because the catalyst can be reused ${ }^{8-10}$. One of heterogeneous catalysts that can be used is dolomite. Dolomite is a natural mineral containing compounds namely $\mathrm{Ca} \cdot \mathrm{Mg}\left(\mathrm{CO}_{3}\right)_{2}$ and several other compounds in small quantities ${ }^{11}$. The use of dolomite as a catalyst in various processes has gained wide attention because it's cheap and environmental friendly ${ }^{12}$.

This research was conducted to use the advantage of dolomite as a heterogeneous catalyst that's environmentally friendly. Dolomite performance as catalyst applied to the trans-esterification reaction between palm oil and methanol yielded biodiesel with various ratios of catalyst to oil, duration and temperature of reactions.

\section{EXPERIMENTAL}

\section{Material and Method}

The materials used in the research are dolomite mineral originating in Kamang - Agam district, cooking oil, methanol and aquadest. 


\section{Catalyst Preparation}

Dolomite was crushed by a crusher to $45 \mu$ fineness size and its composition was characterized by using XRF instrument. The dolomite powder was calcinated for 3 hours at four various temperatures respectively namely $700^{\circ} \mathrm{C}, 800^{\circ} \mathrm{C}, 900^{\circ} \mathrm{C}$ and $1000^{\circ} \mathrm{C}$. Each calcinated powder composition was characterized by XRF instrument.

\section{Characterization of Dolomite Catalyst}

The crystal structure and size of catalyst were analyzed by XRD. The morphology of catalyst surface was characterized by SEM and specific surface area was observed by BET. All characterization processed were applied to original dolomite powder and calcinated dolomite powder in optimum temperature (which has the highest composition of $\mathrm{MgO}$ ).

Optimization of Catalytic Activity of Catalysts Dolomite (CaO.MgO) The catalytic activity of catalyst dolomite $(\mathrm{CaO} \cdot \mathrm{MgO})$ was tested with three parameters namely: the concentration of catalyst to oils, stirring duration and temperature of the trans-esterification reaction.

\section{Applications of Catalyst Dolomite (CaO.MgO) Performed on Biodiesel Manufacture}

Pour 60 grams of methanol into a three - neck flask to suspend 10 grams of catalyst dolomite $(\mathrm{CaO} . \mathrm{MgO})$ while stirring them with a magnetic stirrer. Pour 100 grams of palm oil to the mixture and heat it at $60^{\circ} \mathrm{C}$ for 1 hour with constant stirring speed. Let the reaction mixture be for few minutes until it forms separated solid and liquid phase. The liquid phase is suspected to be methyl ester (biodiesel) and the solid phase is catalyst dolomite $(\mathrm{CaO} \cdot \mathrm{MgO})$. Let the liquid phase be for several minutes until it forms two layers, the bottom layer is glycerol and the top layer is suspected as biodiesel. Biodiesel is tested by using gas chromatography to determine the chemical composition. The biodiesel physical properties are characterized by determining the viscosity, calorific value, and density.

The same treatment is applied to various amounts of catalyst $(5 \%, 10 \%, 15 \%$ and $20 \% \mathrm{~b} / \mathrm{b})$ to palm oil, various times $\left(30,60,120\right.$ and 150 minutes), and various reaction temperatures $\left(40^{\circ} \mathrm{C}, 50^{\circ} \mathrm{C}, 60^{\circ} \mathrm{C}\right.$ and $\left.70^{\circ} \mathrm{C}\right)$.

\section{Characterization of Biodiesel}

Biodiesel composition was determined by using Gas Chromatography Agilent Technologies supported by software of Agilent Technologies Corporation. Column used was J\&W DB-624 with a column length of $30 \mathrm{~m}$ and a volume of $2 \mu$ liter. The stationary phase is silica and use detectors Flame Ionization Detector (FID). Biodiesel physical properties were determined by measuring the viscosity, density and calorific value.

\section{RESULTS AND DISCUSSION}

The dolomite characterization by using XRF obtained content of oxide ${ }^{14}$. In Table-1, it can be seen that there are $\mathrm{MgO} 20.17 \%$ and $\mathrm{CaO} 31.25 \%$. XRD analysis shows that dolomite originating from Kamang in Agam District has a chemical structure with formula $\mathrm{CaCO}_{3} \cdot \mathrm{MgCO}_{3}$, shown in Figure-1a. It can be confirmed to the Standard of ICDD 01-083-1766. The results of dolomite analysis by using XRD that are compared to standard dolomite ${ }^{12}$, can be seen in Figure-1a.

Figure-1a shows that the dolomite in Kamang have peaks which overlaps with standard ICDD 01-0831766 and connects to chemical formula $\mathrm{MgCa}\left(\mathrm{CO}_{3}\right)_{2}$. Sharp peaks appear on $2 \theta 30.934^{\circ}$ and on $41.108^{\circ}$ which is the peak of dolomite with Rhombohedral crystal system. Next, $29.412^{\circ}$ is the peak of calcite $\left(\mathrm{CaCO}_{3}\right)$ that's in accordance with the peak calcite standard of ICDD 01-078-46142. Calcination of dolomite under 4 variations of temperature is obtained from XRF analysis results, shown in Table- 2 . Table-2 shows that the calcined mineral dolomite will decompose into oxide $(\mathrm{CaO}, \mathrm{MgO})$ and $\mathrm{CO}_{2}$ derived from carbonate compound contained in the mineral ${ }^{15}$. From XRF results, $\mathrm{CaO}$ and $\mathrm{MgO}$ havea greater percentage than other oxides and they can reach optimum temperature of calcination up to $900^{\circ} \mathrm{C}$. 
RASĀYAN J. Chem.

Vol. 10 | No. 1 |160-164 | January - March | 2017

Table-1: The Results of XRF Analysis to dolomite in Kamang

\begin{tabular}{c|c}
\hline Compound & Content (\% weight) \\
\hline $\mathrm{CaO}$ & 31,25 \\
\hline $\mathrm{MgO}$ & 20,17 \\
\hline $\mathrm{SiO}_{2}$ & 3,65 \\
\hline $\mathrm{Al}_{2} \mathrm{O}_{3}$ & 0,61 \\
\hline $\mathrm{Fe}_{2} \mathrm{O}_{3}$ & 0,46 \\
\hline $\mathrm{LOI}$ & 43,86 \\
\hline
\end{tabular}

LOI: Loss on Ignition

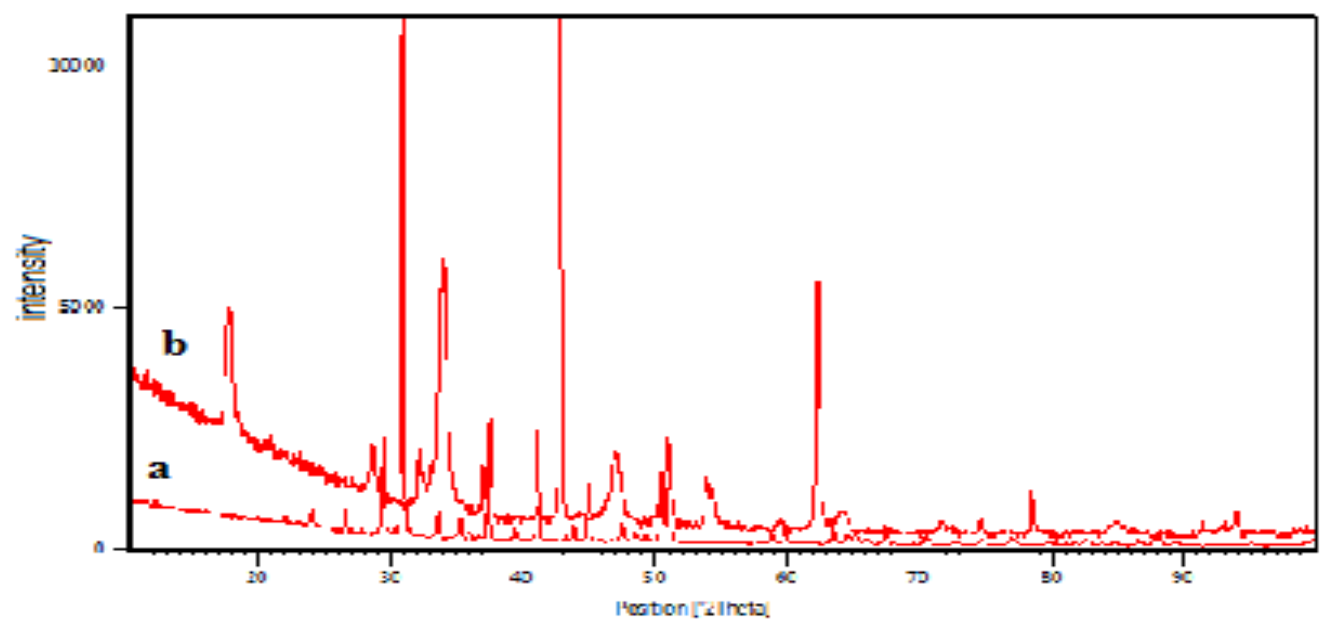

Fig.-1: XRD spectra of the result of (a) dolomite analysis in Kamang (b) dolomite after calcined on temperature $900^{\circ} \mathrm{C}$

Calcination product at the optimum temperature $\left(900^{\circ} \mathrm{C}\right)$ is analyzed by using XRD. The XRD spectra of the compound as a calcination product of dolomite at optimum temperature can be seen in Figure-1b.

Figure-1b shows that the highest peaks are seen in $2 \theta 42.8708^{\circ}$ and $62.253^{\circ}$. By Referring to standard of ICDD 03-065-0476, those peaks are the peaks of $\mathrm{MgO}$ compound with a cubic crystal system. Another peak is seen in $2 \theta 37,2980^{\circ}$ which is the peak of $\mathrm{CaO}$ based on standard of ICDD 01-070-549014.

Morphology analysis and particle size of dolomite and calcined dolomite (CaO.MgO catalyst) are analyzed by using SEM shown in Figure-2a and 2 b. Figure-2a shows that dolomite particles look like heterogeneous lumps form that's colonized and in irregular particle size. Figure $2 \mathrm{~b}$ shows that particle $\mathrm{MgO}$ are colonized so it is difficult to determine the size of its particle. The shapes of the particles resemble cubic. The surface area of dolomite and the catalyst dolomite $(\mathrm{CaO} . \mathrm{MgO})$ are analyzed by using BET and their obtained data are shown in Table-3.

Table-2: The Results of XRF Analysis on post calcined dolomite mineral

\begin{tabular}{c|c|c|c|c|c|c}
\hline Temperature & \multicolumn{6}{|c}{ Compounds of Calcination Result (\%) } \\
\cline { 2 - 7 } Calcination $\left({ }^{\circ} \mathrm{C}\right)$ & $\mathrm{CaO}$ & $\mathrm{MgO}$ & $\mathrm{SiO}_{2}$ & $\mathrm{Al}_{2} \mathrm{O}_{3}$ & $\mathrm{Fe}_{2} \mathrm{O}_{3}$ & LOI \\
\hline 700 & 58,10 & 10,65 & 3,25 & 0,85 & 0,72 & 26,43 \\
800 & 59,02 & 26,67 & 3,05 & 0,81 & 0,70 & 9,75 \\
900 & 60,46 & 32,78 & 3,46 & 0,98 & 0,74 & 1,58 \\
1000 & 56,17 & 9,35 & 3,15 & 0,81 & 0,73 & 29,79 \\
\hline
\end{tabular}

The catalytic activity of catalyst $\mathrm{CaO} . \mathrm{MgO}$ is tested in the trans-esterification reaction to form methyl ester ${ }^{15-16}$. The optimum condition of the reaction can be reached on temperature $60^{\circ} \mathrm{C}$ for 60 minutes reaction $^{17-18}$. Catalyst concentration of $15 \% \mathrm{~b} / \mathrm{v}$ to oil can produce biodiesel up to $78.09 \%$. 
RASĀYAN $J$. Chem.

Vol. 10 | No. 1 |160-164 | January - March | 2017

GC-MS analysis is conducted to determine quantitatively the compound produced as a result of transesterification reaction. The result product is fatty acid methyl ester contained in palm oil. Methyl esters produced are methyl laurate, methyl 9, 15-oktadecadienoat, 14-methyl pentadecanoat, methyl linoleat, methyl oleat, methyl stearat, and methyl 7, 10 hexadecanoat ${ }^{19-20}$. GC-MS analysis of the transesterification reaction product is shown in Table-4.
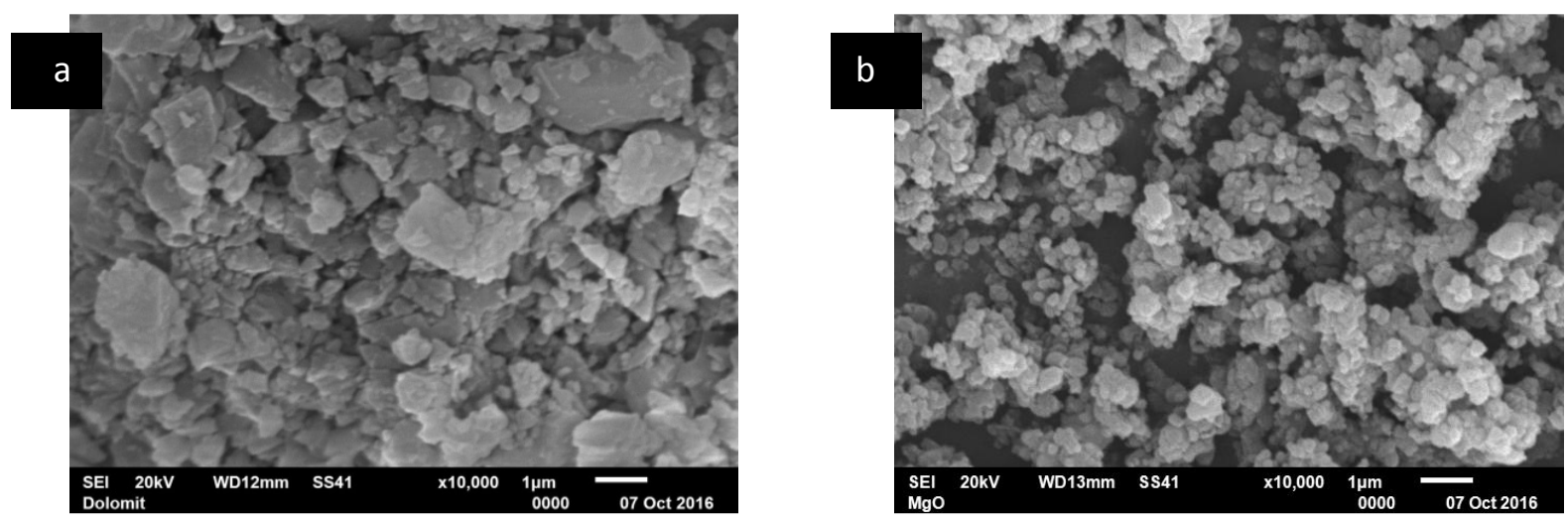

Fig.-2 (a) SEM photograph of dolomite in Kamang after calcinations and (b) before calcinations

Table-3: The surface area of dolomite and catalyst $\mathrm{CaO} . \mathrm{MgO}$

\begin{tabular}{c|c}
\hline Name of Material & Surface Area \\
\hline Dolomite & $0,954 \mathrm{~m}^{2} / \mathrm{g}$ \\
\hline $\mathrm{CaO} \cdot \mathrm{MgO}$ & $6,872 \mathrm{~m}^{2} / \mathrm{g}$ \\
\hline
\end{tabular}

Table-4: GC-MS analysis of Biodiesel compound

\begin{tabular}{c|c|c|l}
\hline Peak & Retention Time & Surface Area (\%) & Methyl Ester \\
\hline 1 & 12.557 & 0.08 & Methyl laurate \\
\hline 2 & 14.865 & 0.07 & Methyl 9,15-oktadecadienoat \\
\hline 3 & 17.705 & 4.10 & 14-Methyl pentadecanoat \\
\hline 4 & 19.346 & 2.81 & Methyl linoleat \\
\hline 5 & 19.440 & 13.54 & Methyl Oleat \\
\hline 6 & 19.680 & 1.91 & Methyl stearate \\
\hline 7 & 21.447 & 0.37 & Arachidic acid, methyl ester \\
\hline 8 & 22.032 & 0.04 & Methyl 7,10-hexadecanoat \\
\hline
\end{tabular}

The characterization of physical properties of produced biodiesel consists of density test, viscosity and caloric value. Table-5 shows the result of physical properties of biodiesel produced from transesterification reaction between oil and methanol and $\mathrm{MgO}$. $\mathrm{CaO}$ catalyst in dolomite and then compared to standard biodiesel (ASTM).

Table- 5 shows that methyl ester produced by palm oil trans-esterification with methanol and $\mathrm{MgO} . \mathrm{CaO}$ as catalyst has passed biodiesel standard value (ASTM) such as density, viscosity and caloric value.

Table-5: The result of Physical Test of Biodiesel

\begin{tabular}{l|l|c|c}
\hline No. & \multicolumn{1}{|c|}{ Parameter } & Result of Analyses & Standard of Biodiesel in Indonesia \\
\hline 1 & Density, $\mathrm{Kg} / \mathrm{m}^{3}$ & 870.5 & $850-890$ \\
2 & Viscosity, $\mathrm{mm}^{2} / \mathrm{s}$ & 5.36 & $2.3-6$ \\
3 & Caloric Value, $\mathrm{cal} / \mathrm{g}$ & 9291.06 & - \\
\hline
\end{tabular}




\section{CONCLUSION}

Calcination of dolomite at optimum temperature of $900^{\circ} \mathrm{C}$ produces oxide $\mathrm{CaO} . \mathrm{MgO}$. This oxide can be used as a catalyst in methyl ester (biodiesel) production. The concentration of catalyst has affected transesterification reaction wherein the concentration of catalyst produces $15 \%$ more methyl ester. Methyl ester (biodiesel) is yielded after 60 -minute reaction under $60^{\circ} \mathrm{C}$ and up to $78.09 \%$. The values of density, viscosity, and calorie of biodiesel produced by trans-esterification reaction with catalyst dolomite ( $\mathrm{CaO} . \mathrm{MgO})$ are qualified based on Standard of Biodiesel (ASTM).

\section{ACKNOWLEDGMENT}

The authors are grateful to Faculty of Mathematics and Natural Science, Andalas University (UA) and Ministry of Research, Technology, and Higher Education for the financial support by Hibah Kompetensi Research Grant No.11/UN.16/Kompetensi/LPPM/2016.

\section{REFERENCES}

1. E. Lotero, Y. Liu, D.E. Lopez, K. Suwannakarn, D.A. Bruce and J.G. Goodwin, Chem. Eng. J., 44, 5353(2005).

2. J. Warren, Earth Science Reviews, 52, 1(2000).

3. S. Kalaiselvan, K. Anitha and P. Shanthi, Rasayan J. Chem.,7, 333(2014).

4. D. Kamisah, Pandiangan, N. Jamarun, S. Arief and W. Simanjuntak, Oriental Journal Of Chemistry, 32, 385(2016).

5. V.N. Ariharan, V.N.D. Meena, S.T.G. Kumar and P.P. Nagendra, Rasayan J. Chem.,7, 129(2014).

6. Z. Kesic, I. Lukic, D. Brkic, J. Rogan, M. Zdujic, H. Liu, and D. Skala, Appl. Catalys, 58-65, 427(2012).

7. N. Jamarun, U. Septiani and R.A. Putri, Der Pharmacia Lettre, 8, 86(2016).

8. S. Chantara-arpornchai, A. Leungnaruemitchai and S. Jai, Chemical and Molecular Engineering, 6, 321(2012).

9. A. Buasri, N. Chaiyut, V. Loryuenyong, P. Worawanitchaphong and S. Trongyong, Sci World J., 460923, 1(2013).

10. B.E. Leach, Applied Industrial Catalysis, 1, 1(1983).

11. O. Ilgen, Appl. Sci. Eng., 92, 452(2011).

12. R.C.R. Santos, R.B. Vieira and A. Valentini, Journal of Catalysts, 213607, 1(2014).

13. J.A.H. Oates, 1998, Lime And Limestone Chemistry And Technology, in: V.C.H Wiley and G.Mbh. Verlag, Production and Uses, Weinheimi, Federal Republic of Germany pp 139-153.

14. http://serc.Carleton.edu/research-education/geochemsheets/techniques/XRD.html

15. M.V. Kok and W. Smykatz-Kloss, Journal of Thermal Analysis and Calorimetry, 91, 565(2008).

16. P. Engler, M.W. Santana, M.L. Mitleman and D. Balazs, The Rigalu Journal, 2, 3(1988).

17. B.R. Jermy and A. Pandurangan, Applied Catalysis. A: General, 288, 25(2005).

18. C. Vieville, Z. Moulooungui and A. Gaset, Industrial Engineering Chemical Research, 32, 2065(1993).

19. S. Selvan, S. Velapan, Rasayan J. Chem., 8, 443(2015).

20. P.K. Sahoo, and L.M. Das, Fuel, 88, 1588(2009).

[RJC-1555/2017] 